\title{
Implementation of Smart Grid System on Alternative Energy of Floating Houses at Musi River Bank Estuary of The Ogan River
}

\author{
Yudi Wijanarko ${ }^{1, *}$ Adi Syakdani ${ }^{1}$ Ekawati Prihatini ${ }^{1}$ Sairul Effendi ${ }^{1}$ Aulia Rizki \\ Utami $^{1}$ Trigitha Melintika ${ }^{1}$ Ryo Pakusadewo ${ }^{1}$ \\ ${ }^{1}$ Politeknik Negeri Sriwijaya, Jl.Srijaya Negara, Bukit Lama, Bukit Besar, Palembang City, South Sumatera 30139 \\ *Corresponding author. Email: wijanarko_yudi@polsri.ac.id
}

\begin{abstract}
Technology has been integrated into daily uses electrical energy as the main energy source. In the utilization of electrical energy, there is a very detrimental waste such as turning on electronic equipment but not being used. In addition to the factor of human negligence, the unmonitored electrical energy used causes ignorance of the wasting of electrical energy. Therefore, this study build a system that can monitor and control the use of electricity based on the Internet of Things with NodeMCU and PZEM-004T devices. NodeMCU equipped with the ESP8266 wi-fi module can transmit data from the PZEM-004T sensor readings via the internet network as the result. The PZEM-004T sensor can read the value of AC voltage (V), AC current (A), Active power (W), power factor (Cos Phi) and used electrical energy $(\mathrm{kWh})$ and frequency.
\end{abstract}

Keywords : Monitoring, NodeMCU, PZEM-004T

\section{PRELIMINARY}

Technological advances increase the consumption of electrical energy in various sectors. The increasing consumption of electrical energy and experience waste such as the use of electrical energy for electronic devices that are not used often happens especially in the household sector. One of the factors causing this problem is the lack of access to monitor the electrical energy used. A controlled monitoring system and the use of the Internet of Things concept is a solution to this problem. Using the NodeMCU microcontroller equipped with the ESP8266 Wi-Fi Module, the reading data obtained from the PZEM$004 \mathrm{~T}$ sensor can be sent via the internet network to a smartphone in a real time.

The controlled monitoring system can be accessed easily and without distance restrictions as long as the device is connected to the internet network. The power consumption monitoring and control system can be implemented in homes, offices, or sectors that use electricity. In this research, the monitoring and control system of used power is installed in a hybrid power plant with AC output coming from the inverter. AC power reading parameters taken from the PZEM-004T sensor are the value of voltage $(\mathrm{V})$, current $(\mathrm{A})$, active power (W), power factor (Cos Phi), electrical energy used $(\mathrm{kWh})$, and frequency $(\mathrm{Hz})$. In addition to displaying the readings from the PZEM-004T sensor, the smartphone application also has a virtual button connected to relays that functions to disconnect and connect the source to the load.

\section{LITERATURE REVIEW}

\subsection{AC Power}

AC voltage and current have a polarity that is always changing, from positive to negative polarity or vice versa. The AC power wave produced by the state electricity company is a sine wave with a frequency of 
$50 \mathrm{~Hz}$. For square and triangular waves are mostly used in inverters [1]

\subsection{Electrical Power}

Electrical power is the delivery rate of electrical energy sent to do in an electrical circuit. The unit of electrical power is Watt or Horsepower (HP) [2]. There are 3 types of power in AC electricity, namely Apparent Power (S), Active Power (P), and Reactive Power (Q). All power consists of active power and reactive power or can be said to be Total Power in units of Volt Ampere (VA). Apparent power can be calculated by the equation :

$$
S=V x I
$$

Active power is the power used on the load in Watts. In AC power, the active power is calculated by the equation:

$$
P=V x I x \cos \varphi
$$

Reactive power is the power used by the load to produce a magnetic field such as a motor in a fan. The unit of reactive power is Voltampere-reactive (VAR) and can be calculated by the equation:

$$
Q=V x I x \sin \varphi
$$

\subsection{Power Factor}

The power factor or also called the phase angle or cos is the ratio between the Active Power (W) and Apparent Power (VA). The phase angle $\varphi$ is the phase difference between the phase voltages and phase currents. The power factor can be calculated by the equation :

Power Factor $=\frac{P}{S}=\frac{\text { V.I. } \cos \varphi}{\text { V.I }}=\cos \varphi$

The power factor value will not be more than 1 and more closer the power factor value is to 1 , the better [3]

\subsection{NodeMCU 1.0}

NodeMCU is a microcontroller device that has been equipped with ESP8266 to connect to the internet network which is commonly used for Internet of Things- based devices. NodeMCU uses Lua for its programming language. The NodeMCU can also be programmed using the Arduino IDE application.

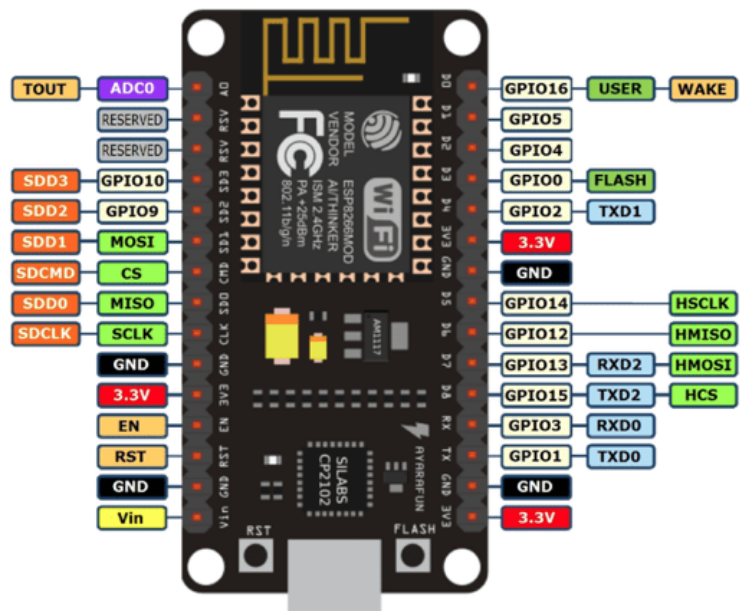

Figure 1. Pinout NodeMCU

\subsection{PZEM-004T Sensor}

PZEM 004T sensor PZEM-004T is a hardware device that functions to measure parameters of voltage, current, active power, and power consumption (kWh). This module also serves all the basic measurement requirements of this PZEM-004T as a separate board. The physical dimensions of the PZEM-004T board are $3.1 \times 7.4 \mathrm{~cm}$ [4]. PZEM-004T Module parameter specifications :

1. Working voltage: 80 - 260VAC

2. Test voltage: 80 - 260VAC

3. Rated power: $100 \mathrm{~A} / 22000 \mathrm{~W}$

4. Operating frequency: $45-65 \mathrm{~Hz}$

5. Measurement accuracy: 1.0

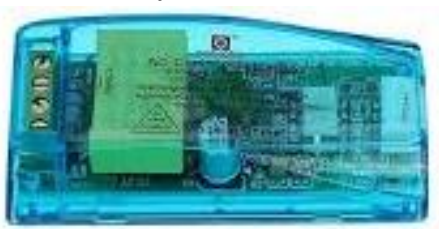

Figure 2. Sensor PZEM-004T 


\section{SYSTEM DESIGN}

System design consists of hardware design and software design. In Figure 3 can be seen the block diagram of the system that is installed in a hybrid power plant.

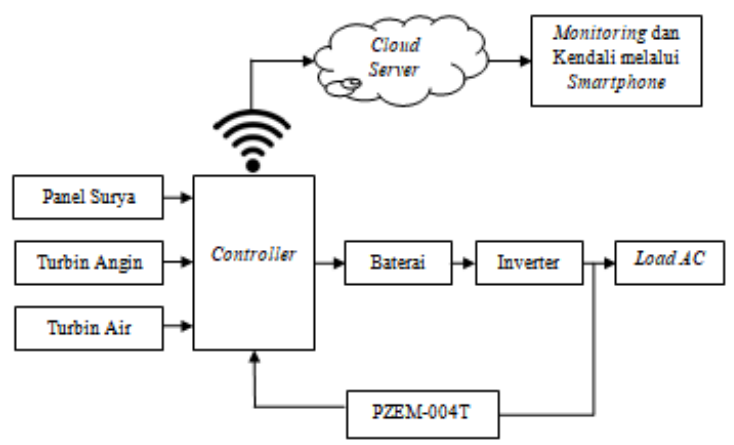

Figure 3. System Block Diagram

\subsection{Hardware Design}

Hardware design consists of circuit schematic and system architecture.

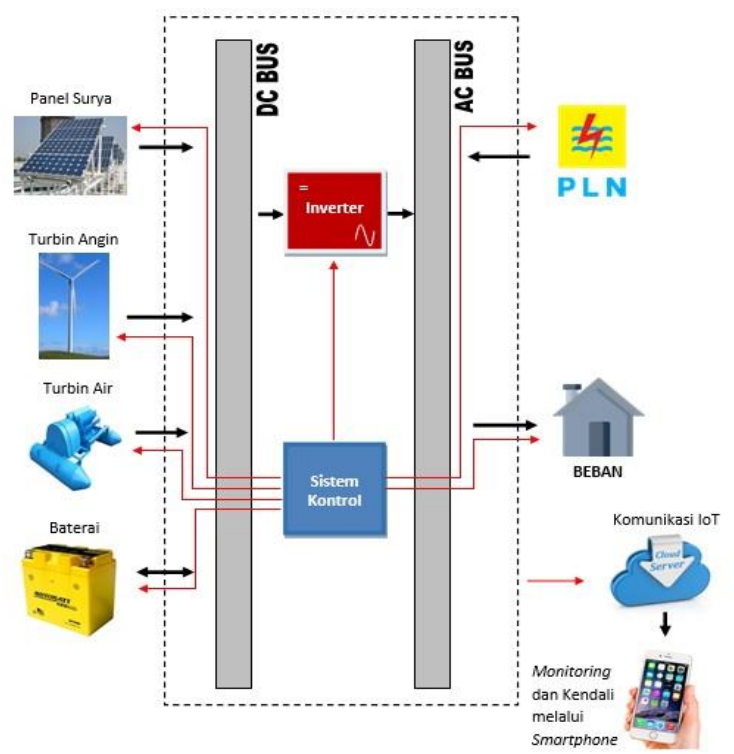

Figure 4. Work Principle of Hybrid System
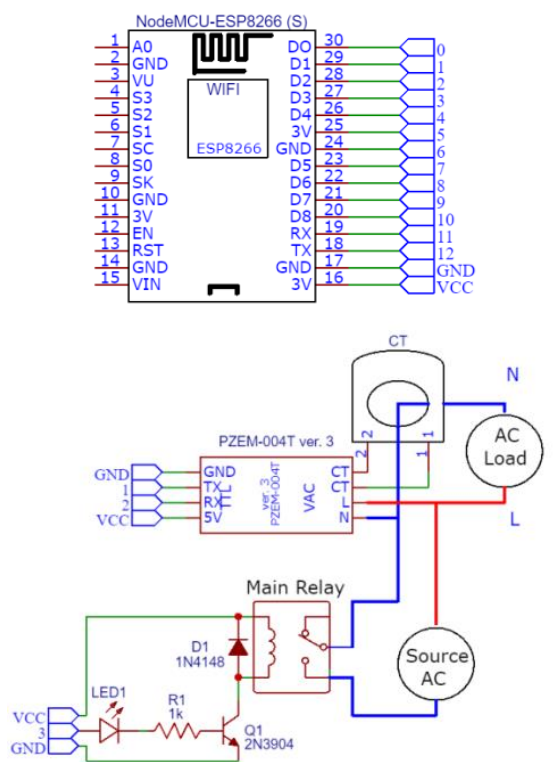

Figure 5. Circuit Schematic

The electronic circuit use a $220 \mathrm{~V}$ AC source from the inverter. To be used by NodeMCU, it uses an adapter and a micro usb cable which is commonly used for charging smartphones with a voltage of $5 \mathrm{~V}$

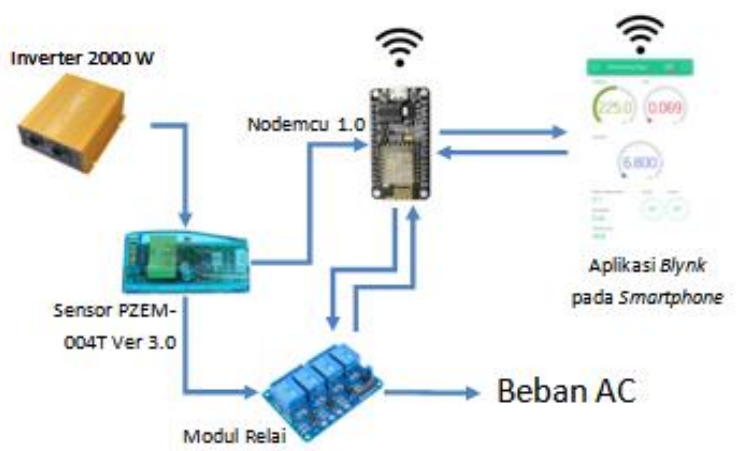

Figure 6. Architectural Design

The PZEM-004T sensor is used to read the voltage and current coming from the inverter and the active power used by the load. The readings from the PZEM-004T sensor will be processed by the NodeMCU which will be sent to the Blynk application display on the smartphone. NodeMCU and smartphone must be connected to the internet to exchange information. The relay is used to connect and disconnect the AC source coming from the inverter to the load. The relay is controlled using a virtual button on the blynk application view. 


\subsection{Software Design}

Software design includes programming and display on the blynk application. Programming using the Arduino IDE application. The program system consists of three main programs, namely the program for the PZEM-004T sensor, the program for connecting to the Blynk application and the program for connecting the ESP8266 to a wi-fi network.

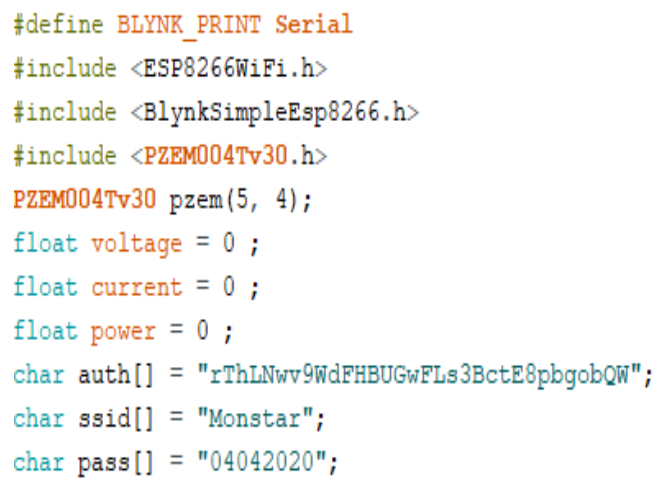

Figure 7. Programs on Arduino IDE

In Figure 7, the ESP8266Wifi library use to connect ESP8266 to wi-fi by filling in the wi-fi name and password in the char ssid and pass. The BlynkSimpleEsp8266 library is used to connect the device to the Blynk application on the smartphone and set by filling in the token sent by the Blynk application as the Blynk account identity and filled in the char. The PZEM004Tv30 library is used to access the PZEM$004 \mathrm{~T}$ sensor to read the required parameters and send data to the NodeMCU.

In Figure 8, the display uses the features in the Blynk application. The value of Voltage, Current, and Active Power use the Gauge display feature, while for the display of the value of energy used, power factor, and frequency use the value display feature in the blynk application. It is also equipped with a virtual button feature that is connected to the relay as load control.

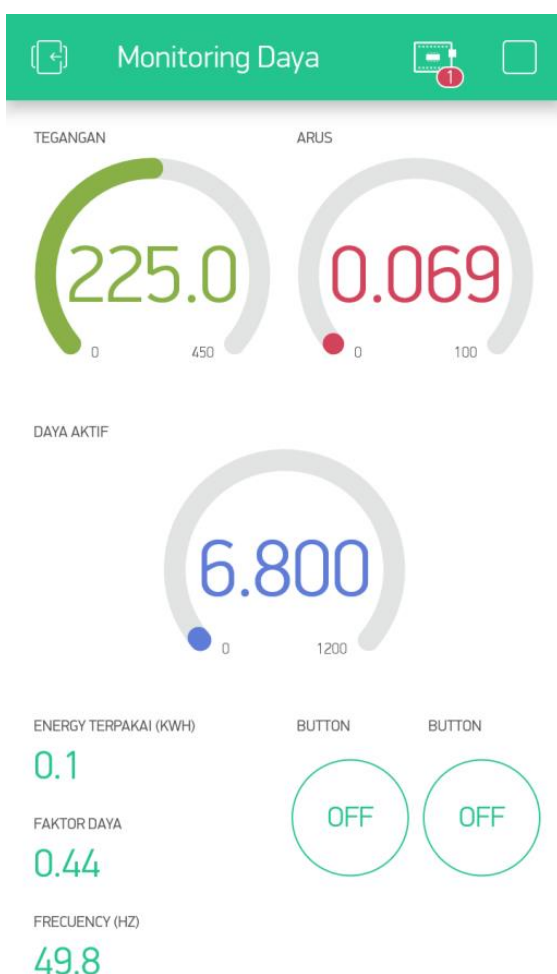

Figure 8. Display on the Blynk Application

\section{RESULTS AND DISCUSSION}

In this result and discussion, a test is conducted with the parameters of the Voltage, Current, and Active Power values to determine whether the PZEM-004T sensor can function properly, also test the relay control function using a virtual button. The test is carried out by comparing the results of the PZEM-004T sensor readings displayed on the Blynk application with standard measuring instruments.

\subsection{Voltage Rated Test}

The test is carried out by comparing the voltage value read by the PZEM-004T sensor with a standard measuring instrument. The voltage is sourced from the inverter and the unit used is Volt (V). 
Table 1. Testing the Voltage Value

\begin{tabular}{|c|c|c|c|}
\hline Load & $\begin{array}{c}\text { Monitoring } \\
\text { System (V) }\end{array}$ & $\begin{array}{c}\text { Measuring } \\
\text { Device (V) }\end{array}$ & $\begin{array}{c}\text { Difference } \\
(\mathrm{V})\end{array}$ \\
\hline No Load & 224,1 & 218 & 6,1 \\
\hline $\begin{array}{c}\text { 3 Watt } \\
\text { Lamp }\end{array}$ & 224,3 & 218 & 6,3 \\
\hline $\begin{array}{c}\text { 7 Watt } \\
\text { Lamp }\end{array}$ & 223,4 & 219 & 4,4 \\
\hline $\begin{array}{c}\text { 10Watt } \\
\text { Lamp }\end{array}$ & 224,2 & 219 & 5,2 \\
\hline $\begin{array}{c}\text { 3 Watt +7 } \\
\text { Watt } \\
\text { Lamp }\end{array}$ & 224,2 & 218 & 6,2 \\
\hline $\begin{array}{c}\text { 10 Watt + 7 } \\
\text { Watt Lamp }\end{array}$ & 224,3 & 219 & 5,3 \\
\hline
\end{tabular}

From the test results data, the voltage value sourced from the $220 \mathrm{VAC}$ inverter, the voltage value does not show the $220 \mathrm{VAC}$ value because there is a voltage tolerance value from the inverter and the error value of the measuring instrument and sensor PZEM004T. There is a difference in the value of the voltage between the system that has been built and the standard measuring instrument. Also obtained values of the average difference calculated by the equation :

$$
\begin{gathered}
\text { Average Difference }=\frac{\text { Total Difference }}{\text { TotalTest }} \\
\text { Average Difference }=\frac{33,5 \mathrm{~V}}{6}=5,58 \mathrm{~V}
\end{gathered}
$$

The difference between the average value of the monitoring system voltage and the measuring instrument is $5.58 \mathrm{~V}$.

\subsection{Current Rated Test}

The test is carried out by comparing the current value read by the PZEM-004T sensor with a standard measuring instrument. The current measured is the current flowing from the inverter as a source to an AC load used in Ampere (A).
Table 2. Current Value Test

\begin{tabular}{|c|c|c|c|}
\hline Load & $\begin{array}{c}\text { Monitoring } \\
\text { System (A) }\end{array}$ & $\begin{array}{c}\text { Measuring } \\
\text { Device (A) }\end{array}$ & $\begin{array}{c}\text { Difference } \\
(\mathrm{A})\end{array}$ \\
\hline No Load & 0,000 & 0,000 & 0,014 \\
\hline $\begin{array}{c}3 \text { Watt } \\
\text { Lamp }\end{array}$ & 0,040 & 0,040 & 0 \\
\hline $\begin{array}{c}\text { 7 Watt } \\
\text { Lamp }\end{array}$ & 0,069 & 0,060 & 0,009 \\
\hline $\begin{array}{c}\text { 10Watt } \\
\text { Lamp }\end{array}$ & 0,080 & 0,08 & 0 \\
\hline $\begin{array}{c}\text { 3 Watt +7 } \\
\text { Watt Lamp }\end{array}$ & 0,096 & 0,090 & 0,006 \\
\hline $\begin{array}{c}\text { 10 Watt + 7 } \\
\text { Watt Lamp }\end{array}$ & 0,130 & 0,130 & 0 \\
\hline
\end{tabular}

From the current value test results data, the average difference value of the system with standard measuring instruments is obtained. The value of the average difference is obtained by the equation :

$$
\begin{gathered}
\text { Average Difference }=\frac{\text { Total Difference }}{\text { TotalTest }} \\
\text { Average Difference }=\frac{0,029 \mathrm{~A}}{6}=0,004 \mathrm{~A}
\end{gathered}
$$

The difference between the average current value of the monitoring system and the measuring instrument is $0.004 \mathrm{~A}$

\subsection{Active Power Value Test}

The active power value test is carried out by loading and measuring the power used by the load and then comparing it with the PZEM-004T sensor readings on the Blynk display. 
Table 3. Active Power Value Test

\begin{tabular}{|c|c|c|c|}
\hline Load & $\begin{array}{c}\text { Monitoring } \\
\text { System (W) }\end{array}$ & $\begin{array}{c}\text { Measuring } \\
\text { Device (W) }\end{array}$ & $\begin{array}{c}\text { Difference } \\
(\mathrm{W})\end{array}$ \\
\hline No Load & 0,0 & 0,0 & 0,0 \\
\hline $\begin{array}{c}\text { 3 Watt } \\
\text { Lamp }\end{array}$ & 3,7 & 3,9 & 0,2 \\
\hline $\begin{array}{c}\text { 7 Watt } \\
\text { Lamp }\end{array}$ & 6,9 & 7,1 & 0,2 \\
\hline $\begin{array}{c}\text { 10Watt } \\
\text { Lamp }\end{array}$ & 9,9 & 10,3 & 0,4 \\
\hline $\begin{array}{c}\text { 3 Watt } \\
\text { +7 Watt } \\
\text { Lamp }\end{array}$ & 10,4 & 10,7 & 0,3 \\
\hline $\begin{array}{c}\text { 10 Watt + } \\
\text { 7 Watt } \\
\text { Lamp }\end{array}$ & 16,7 & 17,4 & 0,7 \\
\hline
\end{tabular}

From the active power value test that has been carried out, the largest difference of the active power value in the $10 \mathrm{~W}+7 \mathrm{~W}$ lamp load test with a difference of $0.7 \mathrm{~W}$. The average difference is also obtained from the results of the active power value test which is calculated by the equation :

$$
\begin{gathered}
\text { Average Difference }=\frac{\text { TotalDifference }}{\text { TotalTest }} \\
\text { Average Difference }=\frac{1,8 \mathrm{~W}}{6}=0,3 \mathrm{~W}
\end{gathered}
$$

The average difference value of the active power between the monitoring system and standard measuring instruments is $0.3 \mathrm{~W}$.

\subsection{Control System Test}

Testing is done by looking at the condition of the relay and load after the virtual button is pressed and the conditions change. The $\mathrm{ON}$ or lit condition is logical 1 and for the OFF condition, it is logical 0.

The relay used is a $5 \mathrm{~V}$ Normally Open Relay Module. The initial condition of this relay is open, which means the circuit is disconnected. After being given a trigger signal, the relay condition will change to normally close which means the circuit is connected in other words the load will be connected to the source and turn on. The trigger signal comes from the NodeMCU which is set via a virtual button on the Blynk application display. The test results data are listed in Table 4.

Table 4. Control System Test

\begin{tabular}{|c|c|c|c|c|c|}
\hline $\begin{array}{c}\text { VB1 } \\
(1 / 0)\end{array}$ & $\begin{array}{c}\text { VB2 } \\
(1 / 0)\end{array}$ & $\begin{array}{c}\text { Relay1 } \\
(1 / 0)\end{array}$ & $\begin{array}{c}\text { Relay2 } \\
(1 / 0)\end{array}$ & $\begin{array}{c}\text { Load } \\
1\end{array}$ & $\begin{array}{c}\text { Load } \\
2\end{array}$ \\
\hline 0 & 0 & 0 & 0 & OFF & OFF \\
\hline 1 & 0 & 1 & 0 & ON & OFF \\
\hline 0 & 1 & 0 & 1 & OFF & ON \\
\hline 1 & 1 & 1 & 0 & ON & ON \\
\hline
\end{tabular}

From the control system testing result, the virtual button provide a trigger signal to the relay via the NodeMCU. Relays working properly in disconnecting and connecting circuits to turn off and turn on the load.

\section{CONCLUSIONS AND SUGGESTIONS}

\subsection{Conclusion}

From the results of testing the power consumption monitoring and control system, it can be concluded as follows :

1. The monitoring system that has been designed and built provide information on Voltage (V), Current (A), Active Power (W), Power Factor (Cos Phi), Electrical Energy used $(\mathrm{kWh})$, and frequency $(\mathrm{Hz})$ displayed on the Blynk application in real time.

2. The average difference value from the test results between the monitoring system and standard measuring instruments is $5.58 \mathrm{~V}$ for the difference in voltage values, $0.004 \mathrm{~A}$ for the difference in current values, and $0.3 \mathrm{~W}$ for the difference in active power values.

3. The control system working properly and the delay from pressing the virtual button until the load turns on depends on the speed of the internet network.

\subsection{Suggestions}

After doing several trials on the system, suggestions for the future are as follows :

1. For display applications from this system, it is better to have your own design rather than using an already available platform because the application may be closed or paid for.

2. The load type is added in the test, especially resistive load and inductive load to get more accurate research results.

3. Improve a more accurate and efficient control system to control loads in daily implementation. 


\section{REFERENCES}

[1] Lister, Sixth Edition 1998. Machinery and Electrical Circuits, Erlangga Publisher.

[2] Hudan, S., IVAN, \& Rijanto, T. (2018). Design and Build of Electrical Power Monitoring System In Internet Of Things (IoT) Based Boarding Rooms. Electrical Engineering, 8(1)
[3] Putra, Deni Adi, \& Riki Mukhaiyar. (2020). Electric Power Monitoring in Real Time . Journal of Vocational Electronics and Informatics Engineering, 8(2).

[4] Alipudin, Asep Muhammad, Didik Notosudjono, \& Dimas Bangun Fiddiansyah. (2018). Design and Build an Internet of Things (IOT) Based Electricity Cost Monitoring Tool. Student Online Journal (JOM) in Electrical Engineering 1 (1). 